\title{
Assessing the Prevalence of Harassment and Abuse in the Nursing Work Environment
}

\author{
Sajma Ajhenberger ${ }^{1}$, Jelena Hodak ${ }^{3 *}$, Dubravka Ivić ${ }^{1}$, Dunja Anić ${ }^{2}$, Ivana Vadlja ${ }^{1}$ \\ ${ }^{I}$ University Hospital Centre Osijek, Croatia \\ ${ }^{2}$ Community Health Centre Osijek, Croatia \\ ${ }^{3}$ University Hospital Centre Zagreb, Croatia
}

*Corresponding Author: Jelena Hodak, University Hospital Centre Zagreb, Croatia

\begin{abstract}
Introduction: Considering high responsibility for human life and health and exposure to specific stressors, the health profession has been classified as a highly stressful one. Nurses are at highest risk for workplace mobbing among healthcare professionals.
\end{abstract}

Aim: To determine are nurses exposed to mobbing in the workplace and what forms of harassment and abuse are present in the nursing work environment.

Subjects and Methods: Respondents are nurses $(n=155)$ who are employed in healthcare institutions in Croatia. Data was collected using a standardized questionnaire regarding negative workplace practice.

Results: Most (84\%) respondents were occasionally exposed to mobbing. The most frequent answers were about ignoring attitudes and opinions, spreading rumors and gossip, and about making inappropriate jokes about employees' work. Middle-aged subjects were more likely to be exposed to negative practices than younger participants, including overwhelmed with meaningless tasks $(P=0.015)$ and excessive workload $(P$ $=0.046)$, being insulted $(P=0.042)$, being suggested that they quit/change jobs $(P=0.032)$ and being intimidated by finger-pointing and blocking safe passage $(P=0.021)$. Respondents with a bachelor's and master's degree were more likely to experience withholding information $(P=0.001)$ and intimidation $(P=$ 0.029).

Conclusion: Nurses are exposed occasionally to harassment and abuse. They consider about their work to be the hardest thing is having their opinions or beliefs ignored, being a target of rumors and gossip and experiencing inappropriate jokes about their work.

Keywords: abuse, harassment, nurses, workplace

\section{INTRODUCTION}

Over the last few decades, there has been a realization that harassment and abuse in the work environment are increasingly permeating modern workplaces and becoming their leading feature (1). Austrian ethologist Konrad Lorenz combined the various forms of harassment and abuse into the common concept of mobbing (2).The first scientist to begin investigating the phenomenon was German psychologist Heinz Leymann. He used the term "mobbing" for certain forms of workplace harassment. According to Leymann's definition, mobbing is hostile and unethical communication systematically directed by one or more persons towards an individual who, because of mobbing, is put to a position where he is helpless and unable to defend himself, and is targeted by persistent mobbing action(3).They are usually powerful people, who desire even more power and for whom mobbing behavior is a way of masking powerlessness in the private sphere, such as in their marriage of family life by forming a group around them to prove their power and importance at the expense of the victim (4). The victims of mobbing are most often people who have high ethical standards and whose positive qualities cause envy. A research shows that younger people who have just been employed individuals who are vulnerable to social injustice, the elderly before retirement, the physically disabled, employees seeking better working conditions and more work independence those seeking to retain 
appropriate professional status and salary increases, as well as individuals who reported work irregularities are more exposed to mobbing (5).Nurses are at highest risk for workplace mobbing among healthcare professionals. Considering high responsibility for human life and health and exposure to specific stressors, the health profession has been classified as a highly stressful one. Workplace stress is becoming a growing problem worldwide and mobbing, as a phenomenon of psychological abuse, is one of the most severe forms of work stress that can have lasting effects on an individual's mental and physical health (6).According to the International Council of Nurses (ICN), harassment and abuse are reported in $30.9 \%$ of Bulgarian, Lebanese $22,1 \%$, South African 20,6\%, Portuguese 20\%, Brazilian 15,2\%, Thai 10,7\%, Australian 10,5\% and $2 \%$ of Italian employees (7). Different prevalence of mobbing in these countries is most likely due to the cultural differences and the attention paid to the phenomenon. In the Republic of Croatia, the investigation of workplace harassment and abuse is only in its infancy (8). In a survey of 1,354 nurses employed in healthcare facilities in 21 counties, $52.65 \%$ of employees gave a positive answer to a question about exposure to some form of harassment and abuse (9). According to the report by the European Association for the Improvement of Living and Working Conditions from December 2000, in EU countries, around 8\% of employees annually are victims of harassment and abuse. As many cases are not reported, the actual situation is unknown. Harassment and abuse in the workplace are known not only to be detrimental to persons exposed to it, and to whom they causes psychological and psychosomatic disorders, but because of reduced work efficiency, excessive absenteeism and consequently increased employee turnover, are associated with high costs for employers and the community. In the US, the cost of harassment and abuse is estimated at $\$ 4$ billion. In Germany, annual costs arising from harassment and abuse for organizations with more than 1,000 employees exceed $\$ 112,000$. According to a study conducted in the UK, harassment and abuse in the workplace most often occur in poorly run organizations and in cases of management disinterest and helplessness (10). The motivation for this research is to obtain information on the scale of this problem in Croatia and to empower nurses and protect their dignity.

\section{RESEARCH OBJECTIVES}

The research objectives are as follows:

a. To examine whether and to what extent nurses are exposed to harassment and abuse in the workplace.

b. To determine what forms of harassment and abuse are present in the work environment of these healthcare professionals.

c. To determine whether age, gender and educational background of nurses influence their exposure to harassment and abuse.

\section{RESPONDENTSAND METHODS}

\subsection{Respondents}

The study included nurses $(\mathrm{n}=155)$ from three Clinical Hospital Centers in the Republic of Croatia (Osijek, Rijeka, Zagreb) employed at anesthesia, surgery, intensive care units, orthopedics, neurology and gynecology clinics. Health professionals of both gender and all levels of education (high school degree, bachelor's and master's degree) were included. Most subjects were female (85.5\%), and more then one-third $(32.9 \%)$ belonged to the age group of 30-39 years, with an average age of 40.5 years (SD 10.89). All respondents were informed of the purpose and manner of conducting the study indicating that their participation was voluntary and anonymous. The study was approved by the Ethics Committees of all participating institutions.

\subsection{Methods}

The study was designed as a cross-sectional study. It started on January 1 and ended on June 30, 2018. Relevant data were collected through the anonymous standardized Questionnaire (NAQ), designed in 1991. by Einarsen and Raknesen and revised in 2009. (12). the questionnaire contains 22 statements. The first part deals with the demographic data of the respondents, while the second part contains questions related to particular forms of abuse and harassment. Based on the answers to individual questions in the second group, it is estimated how often the respondent is exposed to a particular negative procedure. Grades 1 through 5 are offered on a Likert-type scale $(1=$ never, 2 = occasionally, $3=$ monthly, $4=$ weekly, $5=$ daily), with the highest point being the worst. The questionnaire contains three subscales: for personality-targeted abuse, for physical harassment, and for work-related abuse. The seven work-related bullying and statements 
on bullying in the survey were questions number $1,3,14,16,18,19,21$. The three issues related to physical abuse and harassment were issued numbered 8, 9, and 22, while personality -targeted abuse is referred to by 12 issues numbered 2, 4, 5, 6, 7, 10,11, 12, 13,15,17 and 20. The internal reliability of the entire Cronbach Alpha scale is 0.964; domains of harassment at work 0.896, domains of physical abuse 0.718 , and domains of harassment at personal level 0.945 .

\subsection{Statistical Methods}

Categorical data was presented in absolute and relative frequencies. The $\chi^{2}$ test was used to test for differences among categorical variables, and Fisher's exact test was used as needed. All $\mathrm{P}$ values were two-sided. The significance level was set at $\alpha=0.05$. The SPSS statistical program (version 16.0, SPSS Inc., Chicago, IL, USA) was used for statistical analysis.

\section{RESUlts}

Table1: Distribution of respondents by gender, age, education and marital status

\begin{tabular}{|c|c|c|c|}
\hline & & $\mathbf{N}$ & $\%$ \\
\hline \multirow[t]{3}{*}{ Gender } & Male & 22 & 14,2 \\
\hline & Female & 133 & 85,8 \\
\hline & Total & 155 & 100,0 \\
\hline \multirow[t]{6}{*}{ Age group } & $19-29$ Years & 23 & 14,8 \\
\hline & $30-39$ Years & 51 & 32,9 \\
\hline & $40-49$ Years & 43 & 27,8 \\
\hline & $50-59$ Years & 34 & 21,9 \\
\hline & 60 and more Years & 4 & 2,6 \\
\hline & Total & 155 & 100,0 \\
\hline \multirow{4}{*}{$\begin{array}{l}\text { Education } \\
\text { degree }\end{array}$} & High school degree & 108 & 69,7 \\
\hline & Bachelor's degree & 34 & 21,9 \\
\hline & Master' s degree & 13 & 8,4 \\
\hline & Total & 155 & 100,0 \\
\hline \multirow[t]{4}{*}{ Marital status } & Single & 28 & 18,1 \\
\hline & Married & 109 & $\mathbf{7 0 , 3}$ \\
\hline & Divorced & 18 & 11,6 \\
\hline & Total & 155 & 100,0 \\
\hline
\end{tabular}

The study involved 155 subjects. According to the level of education, the most widely (69.7\%). The majority of the study participants were married (70.3\%) (Table1). represented were high school degree subjects

Table2: Forms of harassment and abuse directed at the nursing work environment

\begin{tabular}{|l|l|l|l|l|l|l|}
\hline & \multicolumn{3}{|l|}{ Participants (\%) } \\
\cline { 2 - 8 } & Never & $\begin{array}{l}\text { Occasionall } \\
\mathrm{y}\end{array}$ & $\begin{array}{l}\text { Once } \\
\text { month }\end{array}$ & $\begin{array}{l}\text { Once a } \\
\text { week }\end{array}$ & Daily & $\mathrm{M}$ \\
\hline $\begin{array}{l}\text { Someone withholding information } \\
\text { and affects your performance }\end{array}$ & $50(32,3)$ & $68(43,9)$ & $19(12,3)$ & $7(4,5)$ & $11(7,1)$ & 16,9 \\
\hline $\begin{array}{l}\text { Being ordered to do work below } \\
\text { your level of competence }\end{array}$ & $54(34,8)$ & $56(36,1)$ & $15(9,7)$ & $17(11)$ & $13(8,4)$ & 16,3 \\
\hline Having your opinions ignored & $24(15,5)$ & $73(47,1)$ & $14(9)$ & $23(14,8)$ & $21(13,5)$ & 21,1 \\
\hline $\begin{array}{l}\text { Being given tasks with } \\
\text { unreasonable deadlines }\end{array}$ & $55(35,5)$ & $57(36,8)$ & $14(9)$ & $20(12,9)$ & $9(5,8)$ & 16,1 \\
\hline Excessive monitoring of your work & $32(20,6)$ & $75(48,4)$ & $16(10,3)$ & $16(10,3)$ & $16(10,3)$ & 19,8 \\
\hline $\begin{array}{l}\text { Pressure not to claim something what } \\
\text { you are entitled (e.g. sick leave, } \\
\text { holiday entitlement, travel expenses) }\end{array}$ & $64(41,3)$ & $41(26,5)$ & $18(11,6)$ & $16(10,3)$ & $16(10,3)$ & 14,6 \\
\hline $\begin{array}{l}\text { Being exposed to an unmanageable } \\
\text { workload }\end{array}$ & $26(16,8)$ & $70(45,2)$ & $15(9,7)$ & $21(13,5)$ & $23(14,8)$ & 20,8 \\
\hline
\end{tabular}

In the part of the questionnaire dealing with harassment and abuse directed at the work, the respondents answered occasionally to most questions about the frequency of negative treatment experiences. The most respondents $\mathbf{8 4 \%}$ ) experienced having their personal opinions ignored, while $83 \%$ of the respondents indicated being exposed to an unmanageable workload from daily to occasionally. More than $40 \%$ of participants indicated that they had never been pressured to claim their rights (entitlement to sick leave, annual leave and reimbursement of travel expenses) (Table 2). 
Table3: Forms of harassment and abuse directed at an individual's personality

\begin{tabular}{|c|c|c|c|c|c|c|}
\hline & \multicolumn{5}{|c|}{ Participants (\%) } & \multirow[b]{2}{*}{$\mathrm{M}$} \\
\hline & Never & $\begin{array}{l}\text { Occasion } \\
\text { ally }\end{array}$ & $\begin{array}{l}\text { Once a } \\
\text { month }\end{array}$ & $\begin{array}{ll}\text { Once } & \text { a } \\
\text { week }\end{array}$ & Dail & \\
\hline $\begin{array}{l}\text { Being humiliated or ridiculed in } \\
\text { connection with your work }\end{array}$ & $44(28,4)$ & $73(47,1)$ & $14(9)$ & $15(9,7)$ & $9(5,8)$ & 17,9 \\
\hline $\begin{array}{l}\text { Having key areas of responsibility } \\
\text { removed or replaced with more } \\
\text { trivial or unpleasant tasks }\end{array}$ & $44(28,4)$ & $65(41,9)$ & $19(12,3)$ & $12(7,7)$ & $15(9,7)$ & 17,9 \\
\hline $\begin{array}{l}\text { Spreading of gossip and gossip } \\
\text { about you }\end{array}$ & $24(15,5)$ & $48(31)$ & $21(13,5)$ & $20(12,9)$ & $42(27,1)$ & 21,1 \\
\hline Being ignored or excluded & $40(25,8)$ & $60(38,7)$ & $19(12,3)$ & $15(9,7)$ & $21(13,5)$ & 18,5 \\
\hline $\begin{array}{l}\text { Having insulting or offensive } \\
\text { remarks made about your person, } \\
\text { attitudes or your private life }\end{array}$ & $46(29,7)$ & $55(35,5)$ & $20(12,9)$ & $21(13,5)$ & $13(8,4)$ & 17,5 \\
\hline $\begin{array}{l}\text { Hints or signals from others that } \\
\text { you should leave your job }\end{array}$ & $80(51,6)$ & $45(29)$ & $9(5,8)$ & $16(10,3)$ & $5(3,2)$ & 12,1 \\
\hline $\begin{array}{l}\text { Repeated reminders of your errors } \\
\text { or mistakes }\end{array}$ & $45(29)$ & $73(47,1)$ & $15(9,7)$ & $15(9,7)$ & $7(4,5)$ & 17,7 \\
\hline $\begin{array}{l}\text { Being ignored or facing a } \\
\text { hostile reaction when you } \\
\text { approach }\end{array}$ & $49(31,6)$ & $61(39,4)$ & $14(9)$ & $13(8,4)$ & $18(11,6)$ & 17,1 \\
\hline $\begin{array}{l}\text { Persistent criticism of your errors } \\
\text { or mistakes }\end{array}$ & $31(20)$ & $69(44,5)$ & $15(9,7)$ & $19(12,3)$ & $21(13,5)$ & 20 \\
\hline $\begin{array}{l}\text { Practical jokes carried out by } \\
\text { people you don't get along with }\end{array}$ & $25(16)$ & $72(46)$ & $15(10)$ & $23(15)$ & $20(12,9)$ & 20,9 \\
\hline $\begin{array}{l}\text { Having al legations made against } \\
\text { you }\end{array}$ & $41(26)$ & $68(44)$ & 18 (12) & $14(9)$ & $14(9)$ & 18,3 \\
\hline $\begin{array}{l}\text { Being the subject of excessive } \\
\text { teasing and sarcasm }\end{array}$ & $37(24)$ & $69(45)$ & $19(12)$ & $16(10)$ & $14(9)$ & 19 \\
\hline
\end{tabular}

When answering to personality abuse subscale questions, $84 \%$ of respondents indicated that they had experienced rumors and gossip, as well as unsolicited jokes about their work, while almost $50 \%$ of participants experienced suggestions to leave or change their job (Table 3).

Table4: Forms of physical harassment and abuse

\begin{tabular}{|l|l|l|l|l|l|l|}
\hline \multicolumn{2}{|l|}{} & Participants (\%) \\
\cline { 2 - 7 } & Never & $\begin{array}{l}\text { Occasionall } \\
\mathrm{y}\end{array}$ & $\begin{array}{l}\text { Once a } \\
\text { month }\end{array}$ & $\begin{array}{l}\text { Once a } \\
\text { week }\end{array}$ & Daily & M \\
\hline $\begin{array}{l}\text { Being shouted at or being the target of } \\
\text { sudden anger outbursts }\end{array}$ & $29(18,7)$ & $64(41,3)$ & $19(12,3)$ & $\begin{array}{l}25 \\
(16,1)\end{array}$ & $\begin{array}{l}18 \\
(11,6)\end{array}$ & $\begin{array}{l}20, \\
3\end{array}$ \\
\hline $\begin{array}{l}\text { Intimidating behavior such as } \\
\text { finger-pointing, invasion of personal } \\
\text { space, shoving, blocking your way }\end{array}$ & $83(53,5)$ & $41(26,5)$ & $8(5,2)$ & 16 & 7 & 11, \\
& & & $(10,3)$ & $(4,5)$ & 6 \\
\hline $\begin{array}{l}\text { Threats of violence or physical abuse } \\
\text { or actual abuse }\end{array}$ & $123(79,4)$ & $20(12,9)$ & $10(6,5)$ & 0 & 2 & 5,1 \\
\hline
\end{tabular}

Most respondents (79.4\%) stated that they had never been physically abused or harassed (intimidation, finger-pointing, pushing, block passage and threats of violence). When asked

Table5: Assessment of abuse by domain and by gender whether they experienced outbursts of anger or rage by a superior, $126(81 \%)$ of the respondents answered affirmative (Table 4).

\begin{tabular}{|l|l|l|l|l|}
\hline & \multicolumn{2}{|l|}{ Median (interquartile range) } & & \\
\hline & Male & Female & Total & $\mathrm{P}^{*}$ \\
\hline $\begin{array}{l}\text { The domain of harassment at } \\
\text { work }\end{array}$ & $2,21(1,71-3,32)$ & $2,0(1,57-3)$ & $2,0(1,57-3)$ & 0,52 \\
\hline The domain of physical abuse & $1,83(1,33-2,33)$ & $1,67(1,33-2,33)$ & $1,67(1,33-2,3)$ & 0,76 \\
\hline $\begin{array}{l}\text { The domain of abuse on a } \\
\text { personal level }\end{array}$ & $2,25(1,73-3,15)$ & $2,0(1,58-3,04)$ & $2,1(1,58-3,1)$ & 0,37 \\
\hline Total scale & $2,16(1,34-3,11)$ & $2,0(1,59-3,0)$ & $2,05(1,59-3,05)$ & 0,44 \\
\hline
\end{tabular}

*Mann Whitney U test 
When testing domains within the survey, most respondents responded that they experience abuse on a personal level domain, and the least respondents experienced abuse in the domain of physical abuse. Overall, respondents responded

Table6: Assessment of abuse by domain and by level of education that they experience abuse occasionally and once a month (Table 5). There is no significant difference in abuse by gender and level of education (Table 5 and Table 6).

\begin{tabular}{|l|l|l|l|l|}
\hline \multirow{2}{*}{} & \multicolumn{2}{|l|}{ Median (interquartile range) } & \\
\cline { 2 - 5 } & $\begin{array}{l}\text { High school } \\
\text { degree(n=109) }\end{array}$ & $\begin{array}{l}\text { Bachelor's degree } \\
(\mathrm{n}=34)\end{array}$ & $\begin{array}{l}\text { Master's degree } \\
(\mathrm{n}=12)\end{array}$ & $\mathrm{P}^{*}$ \\
\hline The domain of harassment at work & $2,0(1,6-2,9)$ & $2,29(1,7-3,3)$ & $2,43(1,6-3,3)$ & 0,32 \\
\hline The domain of physical abuse & $1,33(1,3-2,3)$ & $1,67(1,3-3)$ & $1,83(1,1-2,9)$ & 0,4 \\
\hline $\begin{array}{l}\text { The domain of abuse on a personal } \\
\text { level }\end{array}$ & $2,0(1,7-2,9)$ & $2,5(1,6-3,3)$ & $2,13(1,5-3,3)$ & 0,54 \\
\hline Total scale & $1,95(1,6-2,7)$ & $2,5(1,6-3,3)$ & $2,23(1,5-3,3)$ & 0,43 \\
\hline
\end{tabular}

*Kruskal Wallis test

Spearman's correlation coefficient was used to assess the coherence between the age of the subjects and the domains and the overall scale of abuse. There is no significant coherence of age with the domain of abuse at work (Rho =
$-0.077 ; \mathrm{P}=0.34)$, with the domain of physical abuse (Rho $=-0.046 ; \mathrm{P}=0.57$ ), with the domain of personal abuse (Rho $=-0.090 ; \mathrm{P}=0.26$ ), as well as full-scale threads (Rho $=-0.089 ; \mathrm{P}=$ 0.27 )

Table7: Assessment of abuse by domains and by age groups

\begin{tabular}{|l|l|l|l|l|l|}
\hline & \multicolumn{3}{|l|}{ Median (interquartile range) by age } & \\
\cline { 2 - 6 } & $<29$ years & $30-39$ & $40-49$ & 50 and more & $\mathrm{P}^{*}$ \\
\hline $\begin{array}{l}\text { The domain of } \\
\text { harassment at work }\end{array}$ & $1,71(1,43-2,86)$ & $2,29(1,9-3,3)$ & $\begin{array}{l}2,57(1,7 \\
3,4)\end{array}$ & $1,86(1,5-2)$ & $0,003^{\dagger}$ \\
\hline $\begin{array}{l}\text { The domain of } \\
\text { physical abuse }\end{array}$ & $33(1,33-2,0)$ & $1,67(1,3-2,3)$ & $2,0(1,3-3)$ & $\mathrm{z}, 33(1,3-2)$ & $0,01^{\ddagger}$ \\
\hline $\begin{array}{l}\text { The domain of abuse } \\
\text { on a personal level }\end{array}$ & $2,0(1,33-3,0)$ & $2,33(1,7-3,6)$ & $\begin{array}{l}2,42(1,7 \\
3,3)\end{array}$ & $1,83(1,5-2,4)$ & $0,02^{\ddagger}$ \\
\hline Total scale & $1,95(1,45-2,73)$ & $2,23(1,6-3,3)$ & $2,45(1,8-3,3)$ & $1,73(1,5-2,3)$ & $0,007^{\ddagger}$ \\
\hline
\end{tabular}

* Kruskal Wallis test

+ at the level of $P<0.05$ there are significant differences between up to 20 vs. 40-49; 30-39 vs. 50 and over; 40-49 vs. 50 and more

$\neq$ at the level of $P<0.05$ there are significant differences between 30-39vs. 50 and over; $40-49$ vs. 50 and more

Depending on the age, we divided the respondents into age groups. There is a significant difference between all domains and the overall scale of abuse with respect to age. Subjects aged 40-49 were significantly more abused (Table 7).

\section{DISCUSSION}

The purpose of this study was to determine whether and in what forms, harassment and abuse of nurses exist in their work environment and what groups of these health professionals are most vulnerable to mobbing. The study was conducted in three clinical hospital centers (Osijek, Rijeka, Zagreb). The strengths of this research is to obtain data for preventive, educational and protective strategies and the limitations are the smaller number of respondents and hospitals involved in the research. The results of the study show that most of the nurses from these healthcare institutions experience occasionally and once a month certain forms of mobbing in their work environment, including abuse directed at the personal level domain (most frequent answers), as well as some forms of physical abuse and harassment (least frequent answers). The respondents who participated in this study were mostly younger and middle-aged (30 to 50 years of age). The average age of the respondents was 40.5 years (SD 10.89), which corresponds to the age structure of participants in similar studies $(11,12)$. In the studies by foreign authors, the average age of nurses is much lower $(13,14)$. A large number of women were well-represented in the current research, with a significant percentage of $85.8 \%$. This result was expected because nursing is a female-dominated profession. The high proportion of women in the health profession is also evident from the results of most previous studies in the nursing field (15). Almost $70 \%$ of the respondents had a high 
school degree, followed by bachelor's of nursing with a share of $21.9 \%$, while master's of nursing represented $8.4 \%$. The results of study differ from the results of the studies of foreign authors where bachelor's degree holders were most represented, with a percentage of 45 , and master's degree holders were significantly better represented as well. Withholding the information needed for proper work performance being forcing their employees to perform jobs below their level of expertise, ignoring personal views, assigning meaningless tasks, over-controlling, pressuring employees not to ask for what belongs to them, burdening them with excessive workload, humiliating them, assigning inappropriate tasks, spreading rumors, ignoring, insulting and them constantly reminding of their mistakes, compiling unsolicited jokes, presenting unverified information about an individual, shouting, teasing and sarcasm are the forms of abuse and harassment that respondents have identified in the highest percentage as being occasionally exposed to and all perceived as behaviors characteristic of workplace abuse (16).

Similar results have been reported in papers by domestic and foreign authors. The results of the 2009 survey in Washington indicate that 27.3\% of respondents were victims of workplace abuse, while in the 2008. Massachusetts survey, the proportion of victims was $21 \%$ (17). On a scale of 1 to 5 , the lowest point was assigned to ignoring personal attitudes or opinions and being overwhelmed by the workload, experienced by more than $80 \%$ of respondents and that was expected due to insufficient number of health professionals. The most frequent answers to the questions asked were given in the personality harassment and abuse subscale (18). In this study, we also found the similar results. Similar data can be found in a survey conducted in California in 2013, according to more than $80 \%$ of participants experienced the spread of rumors and gossip and unsolicited jokes regarding their work. Many respondents also stated that they were ignored or isolated and experienced unverified employee claims (19). In the reference works spreading malicious gossip, insults, mockery, disclosure of personal information that should not be made available to the public, assigning tasks with the knowledge that the person assigned will not be able to complete the task, ignoring, isolating, denying invitations to meetings and other forms of abuse, are identified as "mobbing". Participants (40\%) in this survey reported experiencing some forms of harassment and abuse, such as experiencing the spread of rumors and gossip, either daily or once a week. The results show that more than $80 \%$ of participants experienced violent behaviors such as shouting and outbursts of rage or anger. Respondents (18\%) are experienced this type of abuse on a daily basis, which is extremely worrying. Workplace violence has a detrimental effect on the physical and mental health of nurses (20), and exposure to mobbing in the work environment may also be a reason for job dissatisfaction and may contribute to a decision to leave the workplace and institution (21). Negative consequences of mobbing at work affect relationships with partners and children, as well as relationships in the family and society in generally. Jeopardizing the social standing and the reputation of individuals has harmful social consequences as it contributes to the disruption of the ethos and ethical standards in social relations (22).

Despite the prevailing view that women are a more vulnerable group and more likely to become a primary target of harassment and abuse (23), the results of study show that no subscale reveals statistically significant differences between men and women in answering questions about harassment and abuse in the work environment. Similar results can be found in a studies conducted by Pranjić et al. in 2006. and Begalinić in 2009. $(24,25)$. Middle-aged respondents were significantly more likely to experience all forms of harassment and abuse than younger respondents. This primarily refers to withholding the information needed for proper work performance, giving meaningless tasks or tasks that cannot be completed within a given timeframe, imposing excessive workload, insulting or ridiculing certain employees backgrounds, attitudes, personal life or habits, and suggesting or alluding that they should leave or change their workplace.

Intimidation tactics such as finger-pointing, pushing, and blocking or preventing passage were also more commonly experienced by middle-aged subjects. The results of study may have been influenced by the small number of respondents and their unequal representation in different age groups. Most respondents, $33 \%$ of them, were between 30 and 49 years old. The results of this study show that health professionals with a college or university degree were more exposed to different forms of harassment and abuse than those with lower 
levels of education. Thus, respondents with master degree most frequently faced withholding information needed for the proper work performance. The latter were also more likely to experience intimidation, such as finger-pointing, pushing, and blocking safe passage, compared to high school degree staff. In his paper published in 2013, Bendinelli states that $27 \%$ of nurses were ordered to perform tasks below their level of expertise or experienced having key areas of responsibility removed and being assigned trivial or inappropriate duties. Such procedures couse the nurse to feel powerless, voiceless, and ultimately oppressed. In Croatia, it has not yet been clarified or regulated how nurses and bachelor's of nursing are different from master's of nursing so most master's of nursing do not work in a workplace that is not commensurate to their level of education. Any abuse, including in the workplace abuse, can contribute to permanent damage to health. In accordance with Article 30. of the Occupational Safety and Health Act, every employer in the Republic of Croatia is obliged to protect the dignity of an employee while performing they job and to provide him/her with working conditions where they will not be exposed to any form of abuse or harassment. A lack of knowledge of the existing laws and a lack of appropriate legislation is probably the reason for the low number of reports of harassment and abuse in the working environment of healthcare professionals. In order to prevent workplace abuse, it is necessary, in cooperation with the employer, to develop prevention programs that define abuse and harassment, as well as sanctions for misconduct. In countries such as Sweden, Norway and Finland, harassment and abuse in the workplace are punishable by law. A way to help abused workers is to create an atmosphere of confidence and awareness that they are all part of single team. Improving psychological climate in the workplace is a way of ensuring socially responsible conduct.

Future research should include the prevention of mobbing (communication skills, conflict resolution, assertive training, and feedback), the protection of workers dignity, educational activities and public campaigns.

\section{CONCLuSion}

The results of this research confirmed that nurses are exposed to mobbing in the workplace, which involves experiencing of harassment and abuse most on personal level and least at physical abuse domain an occasionally and once a month. The most common forms of negative treatment are ignoring personal opinions or beliefs, being overwhelmed by workload, spreading rumors and gossip, making inappropriate jokes about an employees work, shouting and outbursts of anger on personal level domain. Age and level of education significantly influence the incidence of mobbing in the working environment of nurses. Middle-aged employees and those with bachelor's and master's degrees are more exposed to harassment and abuse than younger and less educated employees.

\section{REFERENCES}

[1] Hutchinson ML.Bulling in The Workplace: A Study of Australian Nurses.University of Western Sydney, 2007

[2] Šimić N, Rupić L, Gregov LJ, Nikolić M. Coping and perception of mobbing in nurses of different ages and work experience. Safety, 2015;57(4):305-318

[3] Leymann H. The Content and Development of Mobbing at Work. European Journal of Work and Organizational Psychology.1996;5:165-184

[4] Pražetina Kaleb R. Forms of mobbing and judicial protection of mobbing victims. Safety, 2012;21(4):823-836

[5] Laklija M, Janković J. Mobbing - personal, family and work problems and its prevention. Criminology and social integration. 2010; 18 (1):1-131

[6] Buljubašić A. Representation and impact of mobbing on the work activities of nurses. Hcjz.2011; 7 (26)

[7] International Council of Nurses (ICN): Nurses, always there for you: United against violence. Jean-Marteau, 2001; Geneva

[8] Croatian Parliament, Committee on Gender Equality. Proposal of the Law on Prevention of Harassment at Work. Zagreb, July 2007

[9] Korhan EA, Guler EK, Khorshid L, Eser I.Mobbing Experienced by Nurses Working in Hospitals: An Example of Turkey. IntJ of Caring Sciences. 2014;642-51

[10] Woodman P, Cook, P. Bullying at work: The experience of managers. (2005). Available at https://www.managers.org. uk/sites/default/ files/user35/CMI _- bullying_at_work. Access date 12.10.2019

[11] Marušić M. et al. Introduction to scientific work in medicine. 5th edition Zagreb: Medical edition:2013

[12] Einarsen S, Hoel H, Notelaers G. Measuring exposure to bullying and harassment at work: 
validity, factor, structure and psychometric properties of the Negative Acts Questionnaire -Revised. Work\&Stress. 2009;23: 24-44

[13] Batrnek T. Harassment of nurses and technicians in the workplace. Josip Juraj Strossmayer University of Osijek, Faculty of Medicine Osijek; 2017. Date of access 14.09. 2019

[14] Iglesias MEL, Vallejo RBB. Prevalence of bullying at work and its association with self-esteem scores in a Spanish nurse sample. Contemp Nurse. 2012;42(1):2-10

[15] Johnson S, Rea R. Workplace bullying. Concerns for nurse Leaders. JONA. 2009; 39(2): 84-90

[16] Ajhenberger S, Takač A et al. Satisfaction with the work of nurses and technicians. Shock. 2014; 39-46

[17] Simons S. Workplace bullying experienced by Massachusetts registered nurses and the relationship to intention to leave the organization. Adv Nurs Sci.2008;31(2):48-59

[18] Ajhenberger S. The impact of stress on the working ability of health care staff in an intensive care unit. Master's thesis, Faculty of Medicine Osijek. [Accessed September 14, 2019]

[19] Bendinelli MR. The relationship of disruptive behavior and intent to leave current nursing position. California State University San Marcos: 2013.

[20] Hutchinson M, Jackson D, Wilkes L, Vickers M. H. A new model of bullying in the nursing workplace: Organizational characteristics as critical antecedents. AdvNurs Sci.2008; 31(2):60-70

[21] Simons SR, Mawn B. Bullying in the Workplace - A Qualitative Study of Newly Licensed Registered Nurses. AAOHN J.2010; 58(7):305-11

[22] Lubarda B. Mobbing at work - harassment / intimidation at work - legal aspects, with reference to medical, psycho-social and economic aspects. FFOS, Osijek, 2008

[23] Di Pasquale V. The SFS analyses the extent, structure and consequences of 'mobbing' at the workplace - ie bullying and harassment - in Germany. SFS Institute for Economic and Social Research, WSI, 2002

[24] Pranjić N, Maleš-Bilić Lj, Beganlić A, Mustajbegović J. Mobbing, stress and work ability index among physicians in Bosnia and Herzegovina. Survey Study.Med. J. 2006; 47(5) 750-758

[25] Beganlić A, Pranjić N, Brković A, Batić-Mujanović O, Herenda S. Effects of mobbing on temporary incapacity for work in nurses-technicians. Safety, 200951 (1): 1-9.

Citation: Sajma Ajhenberger, Jelena Hodak, Dubravka Ivić, Dunja Anić, Ivana Vadlja Assessing the Prevalence of Harassment and Abuse in the Nursing Work Environment. ARC Journal of Nursing and Healthcare. 2020; 6(1):23-30. DOI: doi.org/ 10.20431/2455-4324.0601005.

Copyright: (C) 2020 Authors. This is an open-access article distributed under the terms of the Creative Commons Attribution License, which permits unrestricted use, distribution, and reproduction in any medium, provided the original author and source are credited. 